\title{
Kontribusi Kunjungan Rumah terhadap Kesulitan Belajar Siswa
}

\author{
Solihatun Solihatun ${ }^{*}$, Hayu Stevani ${ }^{2}$, Sisca Folastri ${ }^{3}$ \\ 1,2,3 Program Studi Bimbingan dan Konseling, Universitas Indraprasta PGRI, \\ Jakarta, Indonesia. \\ *) Corresponding author, $\equiv$ e-mail: solihatunsolie@gmail.com
}

$\begin{array}{ccc}\text { Received: } & \text { Accepted: } & \text { Published: } \\ \text { 26 January 2021 } & \text { 14 December 2021 } & \text { 31 December 2021 }\end{array}$

\begin{abstract}
Home visits are carried out to see family conditions related to problems faced by children, such as learning difficulties during the Covid-19 pandemic, students lack concentration, do not understand the subject matter, and are less interested in learning. The purpose of this study is to describe home visits, learning difficulties and to determine the contribution of home visits to students' learning difficulties. The research method in this study is quantitative with a simple regression approach. The population is 684 students and the sampling technique is purposive sampling as many as 65 students in class X. The instrument is a scale of home visits and learning difficulties. The data analysis technique uses a simple regression formula. The results showed that home visits contributed to learning difficulties experienced by students by $12 \%$. Based on the ANOVA test or $F$ test, it can be seen that the significance value is 0.005 which is smaller than 0.05 , it can be concluded that home visits have a significant effect on student learning difficulties and their implications in guidance and counseling in the form of follow-up to BK teachers in the implementation of guidance services. groups, content mastery and group counseling.
\end{abstract}

Keywords: Contribution, Home Visit, Difficulty Learning

\begin{abstract}
Abstrak
Kunjungan rumah dilakukan untuk melihat kondisi keluarga terkait masalah yang dihadapi anak, seperti kesulitan belajar di masa pandemi Covid-19 siswa kurang konsentrasi, kurang memahami materi pelajaran, serta kurang tertarik dalam belajar. Tujuan dari kajian ini yaitu untuk mendeskripsikan kunjungan rumah (home visit), kesulitan belajar dan untuk mengetahui kontribusi kunjungan rumah teradap kesulitan belajar siswa. Metode penelitian dalam penelitian ini yaitu kuantitatif dengan pendekatan regresi sederhana. Populasi sebanyak 684 siswa dan teknik penarikan sampel yaitu purposive sampling sebanyak 65 orang siswa kelas $X$. Instrumen berupa skala kunjungan rumah dan kesulitan belajar yang dikembangkan. Teknik analsis data menggunakan rumus regresi sederhana. Hasil penelitian menunjukkan bahwa kunjungan rumah berkontribusi terhadap kesulitan belajar yang dialami oleh siswa sebesar $12 \%$. Berdasarkan uji anova atau $\mathrm{F}$ test, dapat diketahui bahwa nilai signifikansi 0,005 yang lebih kecil dari 0,05 , maka dapat disimpulkan bahwa kunjungan rumah berpengaruh secara signifikan terhadap kesulkitan belajar siswa serta implikasinya dalam bimbingan dan konseling berupa tindak lanjut kepada Guru BK dalam pelaksanaan layanan bimbingan kelompok, pengusaan konten dan konseling kelompok.
\end{abstract}

Kata Kunci: Kontribusi, Kunjungan Rumah, Kesulitan Belajar 


\section{PENDAHULUAN}

Pandemi Covid-19 menjadikan seluruh dunia harus beradaptasi dengan kegiatan dan kehidupan yang baru, tidak terkecuali sekolah atau pada sektor pendidikan. Di Indonesia 45 juta siswa tidak dapat melaksanakan kegiatan belajar seperti biasa di sekolah dan dialihkan pada pembelajran daring (Azzahra, 2020; Khairuddin, 2020). Pembelajaran daring menjadi solusi dalam masa pandemi ini dan semua elemen masyarakat dituntut untuk bisa menjadi fasilitas pendidikan yang baik bagi siswa untuk belajar terutama personil sekolah dan anggota keluarga. Situasi pembelajaran daring ini membuat siswa mengalami kesulitan dalam belajar diantaranya; kurang memahami materi pelajaran, siswa tidak kosentrasi, jaringan internet yang tidak stabil, tugasnya yang diberikan guru banyak, dan campur tangan orang tua dalam membantu tugas anak, dan lain sebagainya (JGS, 2020; Novianti \& Garzia, 2020).

Sejalan dengan penelitian Solihatun (2019) di SDN 05 Ciganjur Jakarta Selatan menurut penuturan wali kelas 4 dan 5 permasalahan kesulitan belajar siswa yang terjadi dikarenakan dua faktor yaitu intern dan ekstern yang diantaranya: kurangnya konsentrasi (tidak fokus), sering terlambat, kurangnya asupan gizi, siswa terisolir, terlalu aktif di kelas, tata tertib sekolah di langgar, kehadiran siswa yang kurang, hasil belajar kurang dari kriteria kelulusan materi, serta keadaan orang tua yang sibuk. Terkait dengan permasalahan di atas menunjukkan bahwa siswa yang tidak dapat mengikuti pelajarannya dengan lancar, tidak dapat belajar dengan sebagaimana mestinya atau gagal dalam mencapai tujuan belajar yang artinya siswa tersebut memiliki masalah dan kesulitan belajar. Meskipun pada dasarnya kesulitan belajar dapat dialami oleh setiap siswa, namun ada siswa yang dapat mengatasi kesulitannya sendiri dan ada yang harus dibantu orang lain. Bahkan ada yang perlu penanganan secara khusus dalam mengatasi kesulitan belajar. Salah satu upaya yang dilakukan adalah melalui pemberian pelayanan bimbingan dan konseling dalam rangka membantu mengatasi kesulitan belajar siswa.

Kesulitan belajar siswa terlihat melalui aspek psikologis, sosial dan fisiologis, dan ada hambatan tertentu dalam mencapai hasil belajar, yang pada akhirnya menyebabkan prestasi akademik mereka lebih rendah dari standar yang ditetapkan oleh kegiatan belajar di sekolah (Idris, 2009; Nuraeni \& Syihabuddin, 2020). Berbagai karakteristik siswa yang berbeda tersebut dimulai dari siswa yang dapat melaksanakan kegiatan belajar dengan lancar dan berhasil tanpa menemui kesulitan, kemudian siswa yang kesulitan belajarnya sedikit, dan siswa yang kesulitan belajarnya lebih besar.

Beberapa faktor tersebut sangat berpengaruh terhadap keberhasilan siswa dalam menempuh kegiatan pembelajaran di sekolah. Fenomena ini kemudian menjadi perhatian bagi para peneliti 
mebahas mengkaji tentang masalah belajar dan berbagai aspeknya terutama selama di rumah, antara lain 1) Sulitnya orang tua dalam memahami materi untuk anak, 2) orang tua kurang memahami cara meningkatkan minat belajar anak, 3) Orang tua sulit membagi waktu antara bekerja dengan mendampingi anak, 4) kurang sabarnya orang tua saat mengajarkan anak, dan beradaptasi dalam penggunaan gadget, dan 5) jangkauan layanan internet yang bermasalah (Wardani \& Ayriza, 2020; Kuswanto et al., 2021; Mastoah \& Zulaela, 2020; )

Selain itu menurut Lerner (dalam Abdurrahman, 2019) Angka pada kejadian (pravelensi) anak yang mengalami kesulitan belajar di usia sekolah yaitu rentangan dari $1 \%$ sampai $30 \%$ (Lovitt dalam Taufik, 2014). Selain itu Abdurrahman (2014) menjelaskan bahwa terdapat $16,52 \%$ dari 3.215 siswa kelas satu sampai enam SD di DKI Jakarta mengalami berkesulitan belajar. Berdasarkan data tersebut jelas terlihat bahwa kesulitan belajar siswa masih terjadi di sekolah.

Kesulitan belajar merupakan suatu keadaan dimana siswa tidak mencapai kompetensi atau prestasi sesuai dengan kriteria standar yang telah ditetapkan (Saidah, 2015). Kondisi tersebut dapat terjadi berdasarkan faktor biologis atau fisiologis, salah satunya yaitu terkait denga kelainan fungsi otak yang lazim, selain faktor biologis kesulitan belajar spesifik juga dari faktor psikologi yang berkaitan dengan rendahnya motivasi dan minat belajar siswa (Solihatun, 2019; Westwood,
2004). Sejalan dengan hal tersebut Solihatun \& Folastri, (2019) juga menjelaskan beberapa masalah yang mempengaruhi kesulitan belajar siswa diantaranya 1) kurangnya konsentrasi (tidak focus), 2) sering terlambat, 3) kurangnya asupan gizi, 4) siswa terisolir, 5) terlalu aktif di kelas, 6) tata tertib sekolah di langgar, 7) kehadiran siswa yang kurang, 8) hasil belajar kurang dari kriteria kelulusan materi, 9) serta keadaan orang tua yang sibuk. Dengan berbagai permasalahan tersebut dapat dipahami bahwa siswa yang tidak dapat mengikuti pelajarannya dengan lancar, tidak dapat belajar dengan sebagaimana mestinya atau gagal dalam mencapai tujuan belajar dipahami bahwa siswa memiliki kesulitan belajar. Pada dasarnya kesulitan belajar dialami setiap siswa dalam belajar, namun beberapa siswa membutuhkan bantuan dalam mengatasi kesulitan belajar. Salah satu upaya dalam membantu adalah melalui layanan bimbingan dan konseling.

Setiap siswa memiliki tanggung jawab untuk belajar baik ketika disekolah maupun di rumah karena belajar yang efektif adalah cara belajar yang berkesinambungan antara apa yang diperoleh di sekolah kemudian dipelajari lagi di rumah. Hal tersebutdikarenakan waktu yang dibutuhkan untuk belajar di sekolah masih kurang sehingga dibutuhkan waktu tambahan untuk lebih memperdalam ilmu yang dimiliki. Seorang siswa hadir di sekolah tujuannya tidak lain kecuali belajar, sebagai bekal untuk menjadi manusia yang berilmu, yang berakhlak, yang mandiri dan bertanggung 
jawab (Suprayitno \& Wahyudi, 2020; Tutuk, 2015).

Dalam memberikan pendidikan setiap pendidik harus dapat mengembangkan kemampuan dan potensi siswa yang dapat menunjang kehidupan kelak sebagai manusia yang bermartabat dan terhormat. Hal tersebut tentunya menjadi tugas bagi para guru kelas dan guru bimbingan dan konseling dalam memberikan layanan pada siswa (Pohan \& Sahputra, 2018). Siswa atau siswi yang mengalami kesulitan belajar diantaranya siswa atau siswi yang mengalami kesulitan prestasi rendah diatas rata-rata yang disebabkan oleh faktor internal yaitu faktor dari dalam diri siswa itu sendiri, seperti inteligensi rendah, lamban dalam mengerjakan tugas, sulit mengikuti dan sulit mengerti pelajaran yang diberikan oleh guru bidang studi di kelas. Adapun yang disebabkan oleh faktor eksternal yaitu faktor dalam diri luar siswa, seperti karena pengaruh lingkungan, kurangnya perhatian dari guru atau orang tua dirumah serta hubungan sosial (Dinata, Lonto, \& Rattu, 2021; Haryatni, 2014; Sianturi, 2016).

Berdasarkan hasil wawancara dengan guru BK di SMK Nasional Depok terkait dengan kesulitan belajar siswa bahwa terdapat motivasi belajar yang turun semenjak pandemi Covid-19 ini, hal tersebut terjadi dikarenakan kurangnya memahami aplikasi pembelajaran baru khususnya pada jurusan yang memakai komputer. Selain itu masalah keluarga juga merupakan salah satu mempengaruhi siswa mengalami kesulitan belajar dikarenakan di masa pandemik seperti ini ada beberapa keluarga siswa mengalami kesulitan keterpurukan ekonomi dan hal ini beberapa dari orang tua siswa yang berpenghasilan yang tidak tetap, dan berpengaruh pada kehidupan sehari dan terkhususnya dalam kondisi belajar siswa.

Oleh karena itu permasalahan kesulitan belajar siswa yang juga dipengaruhi dari orangtua membuat bimbingan dan konseling menjadi salah satu yang penting, karena bimbingan dan konseling bertujuan untuk mengoptimalkan perkembangan siswa baik perkembangan fisik maupun perkembangan psikis, perkembangan akademik maupun perkembangan nonakademik, serta perilaku sosial yang lainnya, termasuk juga dalam kesulitan belajar (Ahmad Susanto, 2018).Adapun upaya yang dilakukan oleh guru BK dalam membantu mengentaskan permasalahan siswa guna mendapatkan informasi yang lengkapserta arah yang akan diberikan efektif yaitu melakukan kunjungan rumah.

Penelitian mengenai kontribusi kunjungan rumah terhadap kesulitan belajar rumah penting untuk dilakukan berkenaan dengan kondisi sosial di masyarakat sekarang ini, yaitu pada saat pandemi sekarang ini dimana dapat dilihat bahwa banyak terjadi permasalahan-permasalahan bagi siswa ketika BDR (Belajar Dari Rumah) sehingga banyak siswa yang mengalami kendala yaitu kesulitan belajar yang dirasakan hal tersebut terjadi dikarenakan beberapa factor yaitu faktor internal dan faktor eksternal. Berdasarkan fenomena di atas 
maka perlu diteliti untuk mendeskripsikan kunjungan rumah dan kesulitan belajar siswa serta adakah kontribusi kunjungan rumah terhadap kesulitan belajar siswa.

\section{METODE}

Metode yang digunakan yaitu kuantitatif dengan pendekatan korelasional. Kajian dilaksanakan di SMK Nasional Depok. Populasi merupakan seluruhsiswa SMK Nasional Depok Jawa Barat yang berjumlah 684. Adapun sampel kajian ini yaitu 65 orang siswa, dengan teknik penarikan sampel melalui purposive sampling yaitu pemilihan sampel berdasarkan pada karakteristik tertentu yang dianggap mempunyai sangkut paut dengan karakteristik populasi yang sudah diketahui sebelumnya". Dengan demikian sampel diambil dari siswa yang telah diberikan kegiatan kunjungan rumah (home visit).

Instrumen kajian menggunakan skala kesulitan belajar (Muchtar dan Rusmin, 2011) dan kunjungan rumah (Prayitno, 2012). Pengadministrasian instrumen dilakukan secara online melalui google formulir, responden mengisi secara sukarela dan tidak adanya proses pembayaran apapun terhadap responden. Setelah instrumen diuji coba diperoleh hasil dengan jumlah butir pernyataan valid sebanyak 10 butir untuk kunjungan rumah dan 31 butir pernyataan valid utuk kesulitan belajar dengan menggunakan likert rating. Adapun siswa yang menjadi uji validitas adalah siswa dengan kelas yang sama namun berbeda sekolah begitu juga untuk instrumen kesulitan belajar. Adapun hasil dari nilai uji Validitas dengan jumlah sampel 65 siswa dengan menggunakan rhitung > rtabel 0,244.

Sedangkan untuk nilai Reabilitas nya adalah sebesar 0,785. Menurut (Sujarweni, 2014) dasar pengambilan uji reliabilitas cronbach alpha dikatakan reliable jika nilai cronbach alpha $>0,6$ maka nilai reliabel penelitian sebesar 0,785 $>0,6$ artinya dapat dikatakan bahwa instrument home visit ini dikatakan reliable. Selanjuntya untuk instrument kesulitan belajar nilai reliabel nya adalah sebesar 0,818, maka nilai reliabel penelitian sebesar $0,818>0,6$ artinya dapat dikatakan bahwa instrument kesulitan belajar ini dikatakan reliable. Teknik analisis data dalam kajian ini menggunakan analisis regresi sederhana dengan dibantu dengan program SPSS versi 25.0 For Windows.

\section{HASIL TEMUAN \\ Kunjungan Rumah}

Tabel 1. Skor Kunjungan Rumah

\begin{tabular}{|c|c|c|c|c|c|c|c|c|c|}
\hline \multirow[b]{2}{*}{$\begin{array}{l}\mathrm{N} \\
\mathrm{O}\end{array}$} & \multirow{2}{*}{ Indikator } & \multicolumn{8}{|c|}{ Skor } \\
\hline & & $\begin{array}{c}\text { Ideal } \\
\text { (rata- } \\
\text { rata) }\end{array}$ & $\begin{array}{l}\text { Ter- } \\
\text { tinggi }\end{array}$ & $\begin{array}{c}\text { Ter- } \\
\text { renda } \\
\mathrm{h}\end{array}$ & total & $\begin{array}{c}\text { rata- } \\
\text { rata }\end{array}$ & $\begin{array}{r}\% \\
\text { rata- } \\
\text { rata }\end{array}$ & $\mathrm{Sd}$ & Ket \\
\hline 1 & Keluarga & 10 & 10 & 2 & 421 & 6.48 & 64.77 & 1.71 & $\mathrm{~T}$ \\
\hline
\end{tabular}




\begin{tabular}{|c|c|c|c|c|c|c|c|c|c|}
\hline & (2) & & & & & & & & \\
\hline 2 & $\begin{array}{l}\text { Pembahasan } \\
\text { Masala } \\
\text { h Klien } \\
\text { (3) }\end{array}$ & 15 & 15 & 5 & 697 & 10.72 & 71.49 & 2.32 & $\mathrm{~T}$ \\
\hline 3 & $\begin{array}{l}\text { Melengkap } \\
\text { idata } \\
\text { (2) }\end{array}$ & 10 & 10 & 3 & 437 & 6.72 & 67.23 & 1.64 & $\mathrm{~T}$ \\
\hline 3 & $\begin{array}{l}\text { Mengemba } \\
\text { ngkan } \\
\text { komitmen } \\
\text { orangtua/ } \\
\text { Wali (3) }\end{array}$ & 15 & 15 & 5 & 636 & 9.79 & 65.23 & 1.94 & $\mathrm{~T}$ \\
\hline \multicolumn{2}{|c|}{$\begin{array}{l}\text { Keseluruhan } \\
\text { (10) }\end{array}$} & 50 & 50 & 19 & 2191 & 33.71 & 67.42 & 5.93 & $\mathrm{~T}$ \\
\hline
\end{tabular}

Berdasarkan tabel dapat diketahui bahwa secara keseluruhan skor ideal adalah sebesar 50, skor tertinggi 50, skor terendah 19, skor total 2191, rata-rata skor 33.71 dengan tingkat capaian responden sebesar $67,42 \%$ dan standar deviasi sebesar 5,93 . Dengan demikian secara keseluruhan skor capaian responden untuk variable kunjungan rumah/home visit berada pada katagori tinggi. Indikator keluarga berada pada kategori tinggi dengan skor ideal sebesar 10, skor tertinggi 10, skor terendah 2, skor total 421 , rata-rata 6.48 , dengan tingkat capaian responden sebesar $64.77 \%$, dengan standar deviasi sebesar 1.71. Selanjutnya pada indikator pembahasan masalah klien, skor ideal sebesar 15 , skor

\section{Kesulitan Belajar}

tertinggi 15, skor terendah 5, skor total 697, skor rata- rata 10.72 dengan tingkat capaian responden sebesar $71.49 \%$, dengan standar deviasi sebesar 2.32 dan berada pada kategori tinggi. Pada indikator melengkapi data berada pada kategori tinggi dengan skor ideal sebesar 10, skor tertinggi 10, skor terendah 3 , skor total 437 , skor rata-rata 6.72 dengan tingkat capaian responden sebesar $67.23 \%$, dengan standar deviasi sebesar 1,64 . Kemudian indikator mengembangkan komitmen orangtua/wali berada pada kategori tinggi dengan tingkat capaian responden sebesar $65.23 \%$.

Tabel 2. Skor Kesulitan Belajar

\begin{tabular}{llccccccccc}
\hline No & \multicolumn{1}{c}{ Indikator } & $\begin{array}{c}\text { Ideal(r } \\
\text { ata- } \\
\text { rata) }\end{array}$ & $\begin{array}{c}\text { Ter- } \\
\text { tinggi }\end{array}$ & $\begin{array}{c}\text { Ter- } \\
\text { rendah }\end{array}$ & total & $\begin{array}{c}\text { Skor } \\
\text { rata- } \\
\text { rata }\end{array}$ & $\begin{array}{c}\% \\
\text { rata- } \\
\text { rata }\end{array}$ & Sd & Ket \\
1 & Kecerdasan & 20 & 20 & 5 & 802 & 12.34 & 61.69 & 2.81 & $\mathrm{C}$ \\
2 & Belajar & 30 & 28 & 8 & 1225 & 18.85 & 62.82 & 3.74 & $\mathrm{~T}$ \\
3 & Sikap & 20 & 20 & 9 & 913 & 14.05 & 70.23 & 2.71 & $\mathrm{C}$ \\
4 & Fisik & 20 & 20 & 8 & 890 & 13.69 & 68.46 & 2.60 & $\mathrm{C}$ \\
\hline
\end{tabular}




\begin{tabular}{llllllllll}
\hline 5 & Emosional & 20 & 20 & 5 & 897 & 13.8 & 69 & 2.98 & $\mathrm{C}$ \\
6 & Gangguanpsikis & 10 & 10 & 3 & 478 & 7.35 & 73.54 & 1.56 & $\mathrm{R}$ \\
7 & Keluarga & 15 & 15 & 6 & 700 & 10.77 & 71.79 & 2.37 & $\mathrm{C}$ \\
8 & $\begin{array}{l}\text { Social } \\
\text { Masyarakat }\end{array}$ & 20 & 20 & 8 & 920 & 14.15 & 70.77 & 2.71 & $\mathrm{C}$ \\
\hline & Keseluruhan & 155 & 142 & 74 & 6825 & 105 & 67.74 & 13.75 & $\mathrm{C}$ \\
\hline
\end{tabular}

\section{Pengujian Persyaratan Analisis}

\section{Uji Normalitas}

Hasil perhitungan uji normalitas ketiga variabel tersebut disajikan pada tabel berikut.

Tabel 3. Hasil Uji Normalitas

\begin{tabular}{ccc}
\hline & KesulitanBelaja & $\begin{array}{c}\text { Kunjungan } \\
\text { Rumah } \\
(\mathrm{Y})\end{array}$ \\
$\mathrm{L}_{\mathrm{o}}$ & 0,200 & 0,021 \\
$\mathrm{~L}_{\text {tab }}$ & 0.214 & 0.214 \\
$\mathrm{el}$ & & \\
\hline
\end{tabular}

Tabel menunjukkan skor LO kedua variabel @ 0,214. Skor Lo variable kunjungan rumah $(X)$ sebesar 0,021 dan variabel kesulitan belajar (Y) sebesar 0,200.
Dengan demikian dapat disimpulkan bahwa dinyatakan bahwa data kedua variabel berdistribusi normal. Hal ini menunjukkan bahwa salah satu syarat untuk analisis regresi sudah dipenuhi.

\section{Uji Linieritas}

Uji linieritas dilakukan untuk melihat apakah masing-masing data variabel kunjungan rumah $(\mathrm{X})$ cenderung membentuk distribusi garis linear terhadap variabel kesulitan belajar (Y). Uji linearitas dilakukan dengan menggunakan program komputer SPSS versi 25. Hasil uji linearitas hubungan variabel kunjungan rumah dengan kesulitan belajardisajikan pada Tabel 4 berikut.

Tabel 4. Hasil Uji Linieritas

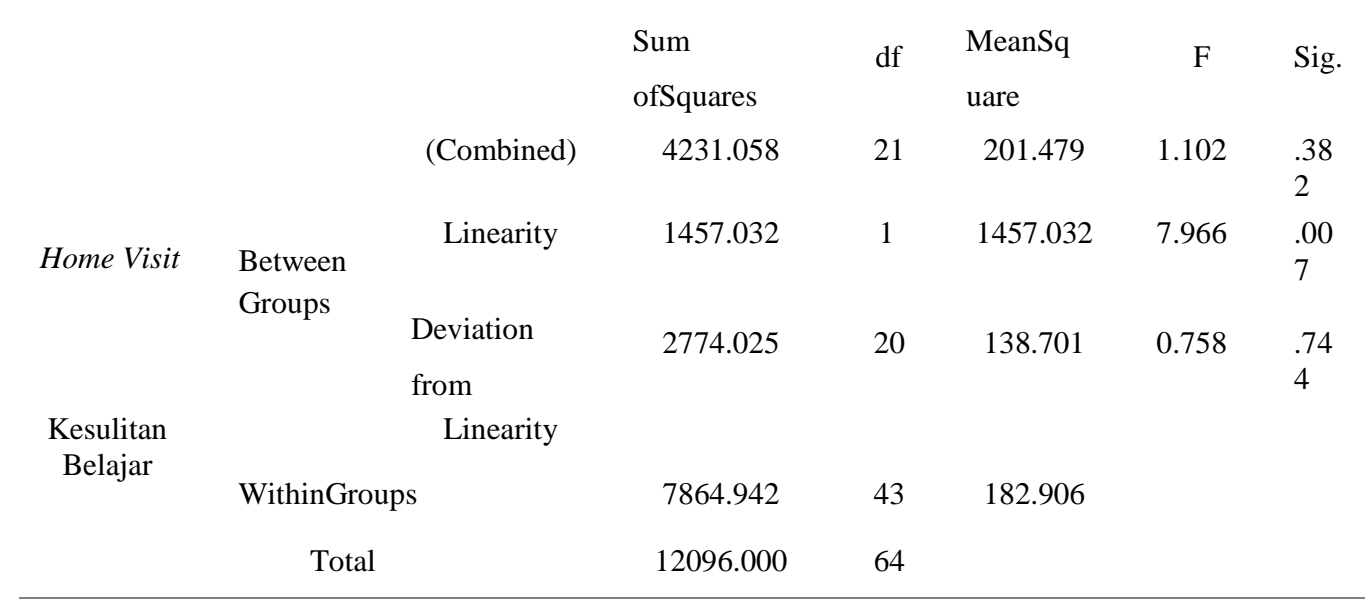

Serta uji linieritas kunjungan rumah 7.966 dengan $\mathrm{p}=0,007(\mathrm{p}<0,05)$ dandeviation from linearity $\mathrm{F}=0.758$ dengan $\mathrm{p}=0,744$. dengan kesulitan belajar diperoleh hasil $\mathrm{F}=$ Hasil tersebut menunjukkan bahwa variabel 
kunjungan rumah dengan kesulitan belajar

Pengujian Hipotesis

bersifat linier atau mengikuti garis lurus.

Tabel 5. Hasil Analisis Korelasi Variabel (X) dengan (Y)

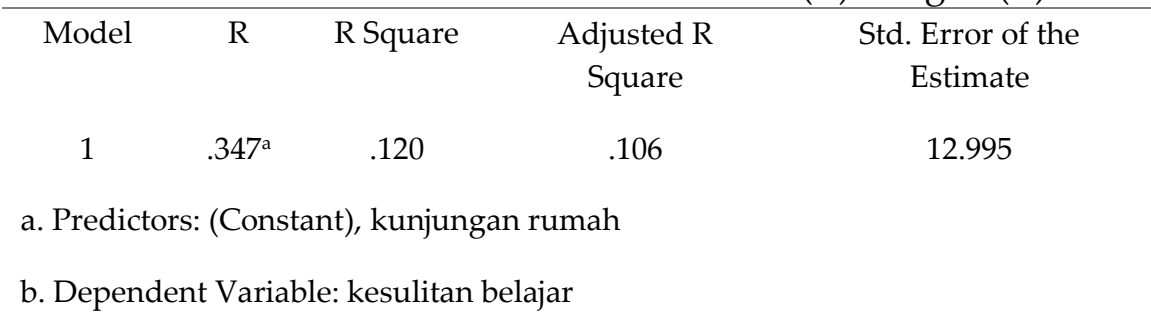

Pada Tabel 5 terlihat, bahwa nilai $\mathrm{R}$

kesulitan belajar. Nilai R Square sebesar sebesar 0,347 yang menunjukkan koefisien 0,120 . Hal ini menunjukkan bahwa $12 \%$ korelasi antara kunjungan rumah dengan kunjungan rumah berkontribusi terhadap kesulitan belajar siswa.

Tabel 6. Hasil Ringkasan ANOVA untuk Uji Signifikansi

\begin{tabular}{|c|c|c|c|c|c|c|}
\hline \multicolumn{7}{|c|}{ ANOVA $^{a}$} \\
\hline \multicolumn{2}{|c|}{ Model } & $\begin{array}{l}\text { Sum of } \\
\text { Squares }\end{array}$ & df & $\begin{array}{l}\text { Mean } \\
\text { Square }\end{array}$ & $\mathrm{F}$ & Sig. \\
\hline 1 & Regression & 1457,032 & 1 & 1457,032 & 8,628 &, $005^{\mathrm{b}}$ \\
\hline & Residual & 10638,968 & 63 & 168,873 & & \\
\hline & Total & 12096,000 & 64 & & & \\
\hline \multicolumn{7}{|c|}{ a. Dependent Variable: Kesulitan Belajar } \\
\hline \multicolumn{7}{|c|}{ b. Predictors: (Constant), Kunjungan Rumah } \\
\hline
\end{tabular}

Berdasarkan Tabel 6 , diperoleh nilai F adalah 8.628 dengan tingkat signifikan 0,005. Probabilitas 0,005 jauh lebih kecil dari taraf signifikan 0,05 yang menunjukkan koefisien korelasi antara kunjungan rumah dengan kesultan belajar adalah signifikan.

\section{PEMBAHASAN}

\section{Kunjungan Rumah}

Temuan penelitian mengungkapkan bahwa secara keseluruhan kunjungan rumah (home visit) berada pada kategori tinggi. Artinya guru BK memiliki semangat yang tinggi dan berupaya melakukan kunjungan rumah seoptimal mungkin untuk membantu permasalahan yang dialami siswa dalam hal kesulitan belajar.

Untuk memecahkan solusi dari setiap masalah yang ada pada peserta didik dalam proses belajar, maka keberadaan home visit semakin dibutuhkan dalam dunia pendidikan. Karena dapat memberikan dampak baik secara langsung maupun tidak langsung. Home visit ini adalah salah satu upaya penting untuk membantu dan membimbing perkembangan sikap anak dan kesulitan yang dihadapi terhadap proses belajar yang berpengaruh terhadap psikologi dankejiwaan anak sesuai dengan tingkat dan situasi termasuk dalam hal motivasi. 
Dalam proses belajar motivasi sangat diperlukan sehingga dapat mempengaruhi hasil belajar siswa. Karena seseorang tidak akan mungkin mempunyai keinginan dan melakukan kegiatan belajar kalau tidak mempunyai motivasi dalam belajar. Home visit dimulai dari hal- hal yang sederhana seperti bagaimana kebiasaan belajarnya, bagaimana sholatnya, bagaimana bersikap terhadap orang tua, kebiasaan makan dan minumnya, itu semua harus dikomunikasikan kepada orang tua supaya mereka tahu kebiasaan yang ada disekolah dengan harapan orang tua bisa membantu mengingatkan ananda saat di rumah.

Kunjungan rumah (KRU) merupakan upaya untuk mendeteksi kondisi keluarga dalam kaitannya dengan permasalahan anak atau individu yang menjadi tanggungjawab Konselor dalam pelayanan konseling. Dengan dilaksanakannya kunjungan rumah akan diperoleh berbagai informasi, keterangan atau data yang dapat digunakan untuk lebih mengefektifkan layanan konseling bagi siswa yang mengalami masalah tesebut. Lebih dari itu, dengan kunjungan rumah Konselor dapat mendorong partisipasi orang tua (dan anggota keluarga lainnya) untuk memperhatihan pemenuhan kebutuhan yang diinginkan oleh anak.

Menurut Prayitno (2012) kunjungan rumah merupakan upaya untuk mendeteksi kondisi keluarga dalam kaitannya dengan permasalahan anak atau individu yang menjadi tanggung jawab guru BK atau konselor dalam pelayanan konseling. Kerjasama dengan orang tua sangat diperlukan dengan tujuan untuk memperoleh keterangan dan membangun komitmen dari pihak orangtua/keluarga untuk mengentaskan permasalahan siswa. Sejalan dengan hasil penelitian oleh (Wahyuni, Ilyas, \& Yusri, 2013) menyatakan bahwa Guru BK/Konselor telah memilih masalah-masalah siswa memerlukan kunjungan rumah buktinya $51,61 \%$ guru $\mathrm{BK} /$ Konselor melakukan kunjungan rumah terhadap siswa yang berprestasi rendah dalam belajar, 67,74\% guru BK/Konselor melakukan kunjungan rumah terhadap peserta didik yang datang terlambat. Selanjutnya menurut (Tohirin, 2009) dalam melaksanakan kunjungan rumah Guru BK/Konselor menyusun jadwal kunjungan rumah yaitu mengkomunikasikan jadwal kunjungan rumah kepada berbagai pihak yang terkait dalam kunjungan rumah seperti orangtua dan peserta didik.

Agar kegiatan kunjungan rumah berjalan dengan baik sesuai dengan dengan tujuan yakni untuk mengentaskan permasalahan yang dihadapi siswa, dimana sangat berpengaruh terhadap prestasi belajar. Jadi perlu adanya perencanaan dan persiapan yang matang dari guru BK dan kerjasama dengan orang tua serta atas persetujuan kepala sekolah untuk kesuksesan kegiatan pendukung bimbingan dan konseling di sekolah.

\section{Kesulitan Belajar Siswa}

Berdasarkan hasil analisis menunjukkan bahwa gambaran kesulitan belajar yang dialami siswa selama pembelajaran dari rumah (daring) berada pada kategori cukup. Hal ini berarti kesulitan belajar yang dialami oleh siswa 
selama pandemi cukup sulit dirasakan. Permasalahan ini terjadi karena berbagai faktor, baik faktor internal maupun faktor eksternal.

Masalah kesulitan belajar merupan suatu kondisi aktual yang dialami siswa di sekolah. Fenomena lapangan menunjukkan bahwa di penghujung tahun ajaran sebagian siswa bahkan orang tua merasa cemas melihat laporan hasil belajar yang diperoleh (di mana hasilnya rendah). Apalagi pada saat ini dengan situasi pandemi semua aktivitas belajar dari rumah (daring), banyak siswa bahkan oragtua mengeluhkan kondisi tersebut. Siswa kurang memahami penjelasan materi pelajaran yang disampaikan oleh guru, terdapat guru yang hanya memberikan tugas tanpamemberikan penjelasan materi terlebih dahulu, siswa dihadapkan untuk mengerjakan tugas yang terlalu banyak yang membuat siswa merasa jenuh, dan tidak semangat mengikuti pembeajaran.

Diagnosis kesulitan belajar merupakan usaha untuk meneliti kasus, menemukan gejala, penyebab, dan menemukan serta menetapkan kemungkinan bantuan yang akan diberikan terhadap siswa yang mengalami kesulitan belajar. Selanjutnya kesulitan belajar dapat berarti suatu kondisi dalam proses belajar mengajar yang ditandai oleh hambatan-hambatan untuk mencapai hasil belajar yang diharapkan. Hambatan ini dapat bersifat psikologis, fisiologis ataupun sosiologis dalam keseluruhan proses belajar seseorang siswa. Hambatan tersebut adakalanya disadari oleh individu yang mengalami kesulitan belajar dan adakalanya tidak, sehingga hasil belajar yang dicapai tidak sesuai dengan semestinya, atau hasil yang dicapai oleh siswa di bawah dari yang semestinya dapat dicapai.

Faktor eksternal yang pengaruhnya terhadap proses dan hasil belajar siswa adalah: Lingkungan keluarga, meliputi antara lain: 1) hubungan antar sesama anggota keluarga, 2) keadaan ekonomi keluarga, 3) aspirasi keluarga terhadap pendidikan, 4) perhatian, motivasi serta perlakuan orang tua/anggota keluarga terhadap kegiatan belajar siswa, lingkungan sekolah: 1) keadaan fisik sekolah, 2) kurikulum, 3) sarana dan fasiitas, 4) guru/personil sekolah lainnya, 5) hubungan antar siswa, dan 6) disiplin. Lingkungan masyarakat antara lain meliputi: 1) pergaulan antar remaja atau teman sebaya, 2) media masa, 3) dunia kerja, dan 4) nilai/norma masyarakat, terkait faktor eksternal ini sejalan dengan pernyataan (Suhendra, 2018) menyebutkan bahwa faktor masyarakat merupakan salah satu sumber belajar yang amat penting dan memiliki nilai-nilai yang sangat berharga dalam rangka proses pembelajaran siswa dan dapat memperkaya bahan dan kegiatan belajar. lingkungan masyarakat di mana siswa berada juga berpengaruh terhadap semangat dan aktivitas belajarnya. Lingkungan (environment) sebagai dasar pengajaran merupakan faktor kondisional yang mempengaruhi tingkah laku individu dan merupakan faktor belajar yang penting. 
Kunjungan Rumah Berkontribusi terhadap Kesulitan Belajar Siswa

Temuan penelitian menunjukkan bahwa terdapat kontribusi yang signifikan antara kunjungan rumah/home visit terhadap kesulitan belajar. Hal ini berarti bahwa kunjungan rumah yang dilakukan oleh Guru BK berpengaruh dalam membantu siswa yang mengalami kesulitan belajar. Kegiatan belajar bagi siswa merupakan kegiatan yang terkadang dirasa tidak menyenangkan. Banyak alasan yang sering diungkapkan oleh para pendidik (baik orang tua maupun guru) bahwa belajar adalah sesuatu yang membosankan bagi siswa. Keluhan yang dikemukakan tersebut dapat menjadi hambatan ataupun penyebab munculnya kesulitan dalam belajar. Jika kesulitan belajar ini tidak dapat tertangani dengan baik maka akan menjadikan prestasi siswa tidak baik pula.

Kesulitan belajar merupakan suatu kondisi dimana siswa mengalami permasalahan belajar, sebagai mana dikemukakan Dalyono (2001) menyatakan bahwa kesulitan belajar adalah hambatan atau gangguan belajar pada siswa yag ditandai oleh adanya kesenjangan yang signifikan antara taraf intelegensi dan kemampuan akademik yang seharusnya dicapai. Sejalan dengan pendapat tersebut, Kullase (2007) berpendapat bahwa kesulitan belajar dapat diartikan sebagai suatu kondisi dimana kompetensi atau prestasi yang dicapai tidak sesuai dengan kriteria standar yang telah ditetapkan.

Kunjungan rumah adalah kegiatan pendukung bimbingan konseling untuk memperoleh data, keterangan, kemudahan dan komitmen bagi terentaskannya permasalahan klien melalui kunjungan ke rumahnya. Melalui kunjungan rumah, proses penyelesaian masalah konseli bisa dilakukan secara kolaboratif dengan melibatkan peran orang tua atau keluarga. Kegiatankunjungan rumah memiliki kontribusi yang positif dalam membantu permasalahan yang dialami oleh siswa, guru BK memahami dan tahu bagaimana kondisi belajar siswa di rumah (Prayitno, 2012). Pun juga membantu Guru BK dalam memberikan pelayanan yang tepat guna dalam pengembangan diri peserta didik.

Dalam merencanakan kunjungan rumah, konselor mempersiapkan berbagai informasi umum dan data tentang siswa yang layak diketahui oleh orang tua dan anggota keluarga lainnya dengan catatan tidak melanggar asas kerahasiaan klien dan semata-mata untuk pendalaman masalah dan penuntasan penanganannya.Selain itu, tidak merugikan siswa dalam kaitannya dengan kedudukan dan hubungan kekeluargaan dalam keluarga yang bersangkutan, hubungan sosioemosional, pemberian kesempatan dan fasilitas serta keterkaitan kerja.

Ada tiga komponen pokok berkenaan dengan kunjungan rumah, yaitu kasus, keluarga dan konselor. Pertama, kasus kunjungan rumah difokuskan pada penanganan kasus yang dialami oleh klien (siswa) yang terkait dengan faktor-faktor keluarga. Kasus siswa terlebih dahulu dianalisis, dipahami, disikapi dan diberikan (dilaksanakan) perlakuan awal tertentu, dan selanjutnya diberikan pelayanan bimbingan dan konseling memadai.Perlakuan awal 
terhadap kasus dilakukan melalui kunjungan rumah. Hasil kunjungan rumah digunakan dalam pelayanan bimbingan dan konseling.Kunjungan rumah juga dapat merupakan bagian langsung dan tindak lanjut (follow up) pelayanan bimbingan konseling terlebih dahulu terhadap kasus yang dimaksud. Kedua, keluarga. Keluarga yang menjadi fokus kunjungan rumah meliputi kondisi-kondisi yang menyangkut orang tua atau wali siswa, anggota keluarga yang lain, orang-orang yang tinggal dalam lingkungan keluarga yangbersangkutan, kondisi fisik rumah, isinya dan lingkungannya dan kondisi ekonomi dan hubungan sosio emosional yang terjadi dalam keluarga. Semua kondisi yang berkenaan dengan keluarga di atas, di analisis dan dicermati dalam kaitannya dengan diri dan permasalahan (kasus) siswa. Selanjutnya, keterkaitan kondisikondisi di atas ditindaklanjuti dengan komitmen seluruh keluarga untuk kepentingan siswa.

Kedua, keluarga dalam pelaksanaan kunjungan rumah meliputi kondisi-kondisi yang berkaitan dengan orang tua atau wali siswa, anggota keluarga yang lain, orangorang yang tinggal dalam lingkungan keluarga yang bersangkutan, kondisi fisik rumah,ekonomi dan sosio emosional keluarga (Hamidi, 2017). Semua kondisi tersebut di analisis dan dicermati dalam kaitannya dengan diri dan permasalahan (kasus) siswa. Sehingga berdasarkan kondisi tersebut dapat ditindaklanjuti dengan komitmen dari seluruh keluarga untuk kepentingan siswa. Ketiga, konselor (guru bimbingan konseling) menjadi perencana, pelaksana, dan pengguna hasilhasil dari pelaksanaan kunjungan rumah. Selanjutnya seluruh kegiatan tersebut dikaitkan langsung dengan pelayanan bimbingan konseling dan kegiatan pendukung layanan bimbingan konseling lainnya. Hal ini sejalan dengan temuan (Hariyadi, 2012) bahwa motivasi belajar siswa kelas XII IPA 2 di SMA Negeri 2 Ungaran sebelum diberikan layanan penguasaan konten dengan dukungan tampilan kepustakaan berbasis TIK menunjukkan kategori sedang dan sesudah diberikan perlakukan laya- nan penguasaan konten dengan dukungan tam- pilan kepustakaan berbasis TIK menunujukkan kategori cukup tinggi. Sehingga dapat dikatakan bahwa dengan layanan penguasaan konten dan kegiatan pendukung tampilan kepustakaaan siswa mampu memiliki motivasi yang tinggi dan berkurangnya kesulitan belajar siswa.

Adapun keterbatasan kajian ini antara lain waktu dalam pengisian data oleh responden yang diberikan bukan pada waktu dekat dalam melaksanakan kunjungan rumah, namun yang pernah menerima kunjungan rumah dalam rentang waktu satu tahun terakhir. Kemudian bagi peneliti selanjutnya diharapkan dapat melanjutkan dengan variabel faktor-faktor yang mempengaruhi kesulitan belajar dan layanan bimbingan konseling seperti layanan bimbingan kelompok dan konseling kelompok.

\section{SIMPULAN}

Berdasarkan hasil kajian dapat disimpulkan bahwa gambaran kunjungan 138 
rumah yang dilakukan Guru BK dalam membantu kesulitan belajar siswa berada pada katerori tinggi, gambaran kesulitan belajar siswa SMK Nasional Depok berada pada kategori cukup dan kunjungan rumah berkontribusi terhadap kesulitan belajar siswa SMK Nasional Depok. Oleh sebab itu Guru BK berperan penting dalam mencegah serta mengentaskan kesulitan belajar siswa dengan memberikan pelayanan konseling sesuai dengan kebutuhan siswa dan melakukan kegiatan pendukung lainnya.

\section{UCAPAN TERIMA KASIH}

Terima kasih kepada semua pihak yang telah membantu dalam pelaksanaan penelitian dan penulisan artikel ini, terutama Program Studi Bimbingan \& Konseling Universitas Indraprasta PGRI, teman sejawat, Kepala Sekolah, Guru BK dan seluruh siswa/i SMK Nasional Depok.

\section{DAFTAR PUSTAKA}

Abdurrahman, M. (2014). Pendidikan bagi anak berkesulitan belajar. Journal Mimbar PGSD Universitas Pendidikan Ganesha, 2(1).

Abdurrahman, M. (2019). Anak berkesulitan belajar. Retrieved from https://r2kn.litbang.kemkes.go.id/handl e/123456789/76504. di unggah pada tanggal 13/12/21.

Ahmad Susanto, M. P. (2018). Bimbingan dan konseling di sekolah: Konsep, teori, dan aplikasinya. Kencana.

Azzahra, N. F. (2020). Mengkaji hambatan pembelajaran jarak jauh di Indonesia di masa pandemi Covid-19. Retrieved from https://repository.cips- indonesia.org/id/publications/30916/

Dinata, I. M. A., Lonto, A. L., \& Rattu, J. (2021). Faktor-faktor penyebab kesulitan belajar siswa dalam mata pelajaran PKN di masa pandemi Covid-19 di SMP Negeri 1 Dumoga. Jurnal PPKn: Media Kajian Pancasila Dan Kewarganegaraan, 1(2), 87-96.

Hamidi, F. (2017). Metode home visit dalam meningkatkan perhatian orang tua pada anak (Studi di SMP Islam YAPKIN AnNur Kp. Kerangkeng, Ds. Buni Bakti, Kec. Babelan, Kab. Bekasi). Universitas Islam Negeri" Sultan Maulana Hasanuddin" BANTEN.

Hariyadi, S. (2012). Upaya meningkatkan motivasi belajar melalui layanan penguasaan konten dengan dukungan tampilan kepustakaan berbasis TIK di SMA Negeri 2 Ungaran. Indonesian Journal of Guidance and Counseling: Theory and Application, 1(1).

Haryatni, A. P. (2014). Identifikasi faktorfaktor penyebab kesulitan belajar pada siswa SMP Negeri 5 kota Jambi. Skripsitidak Diterbitkan. Jambi: FKIP Universitas Jambi.

Idris, R. (2009). Mengatasi kesulitan belajar dengan pendekatan psikologi kognitif. Lentera Pendidikan: Jurnal Ilmu Tarbiyah Dan Keguruan, 12(2), 152-172.

JGS, J. G. S. (2020). Difficulty analysis of physics students in learning online during pandemic Covid-19. Jurnal Geliga Sains (JGS): Jurnal Pendidikan Fisika, 8(1), 49-55.

Khairuddin, K. (2020). Kepemimpinan kepala sekolah di tengah pandemi Covid-19. Edukasi, 8(2), 171-183. 
Kuswanto, K., Kemalasari, P., \& Fadillah, N. (2021). Problematika orangtua saat mendampingi anak dalam pembelajaran daring. Journal of Multilitarcies, 1(1), 17-22.

Mastoah, I., \& Zulaela, M. S. (2020). Kendala orang tua dalam mendampingi anak belajar pada masa Covid 19 di Kota Serang. As-Sibyan: Jurnal Pendidikan Anak Usia Dini, 5(2), 121-128.

Novianti, R., \& Garzia, M. (2020). Parental engagement in children's online learning during covid-19 pandemic. Journal of Teaching and Learning in Elementary Education (Jtlee), 3(2), 117-131.

Nuraeni, N., \& Syihabuddin, S. A. (2020). Mengatasi kesulitan belajar siswa dengan pendekatan kognitif. Jurnal BELAINDIKA (Pembelajaran Dan Inovasi Pendidikan), 2(1), 19-20.

Pohan, R. A., \& Sahputra, D. (2018). Sistem pelayanan konseling bagi siswa berkesulitan belajar. In Prosiding Seminar Nasional Hasil Pengabdian (Vol. 1, No. 1, pp. 228-232).

Saidah, N. N. (2015). Penerapan konseling realita untuk mengatasi kesulitan belajar pada siswa Kelas X SMA 2 Kudus tahun pelajaran 2012/2013 (Studi Kasus Pada Siswa Broken Home). Universitas Muria Kudus.

Sianturi, S. (2016). Analisis kesulitan belajar dan hubungannya dengan hasil belajar siswa pada mata pelajaran Biologi siswa kelas $X$ di SMA Negeri 1 Sidikalang tahun pembelajaran 2015/2016. UNIMED.

Solihatun, S. (2019). Gambaran kesulitan belajar siswa serta implikasinya terhadap pelayanan bimbingan dan konseling. Jurnal Counseling Care, 2(2), 56-64.

https://doi.org/https://doi.org/10.22202 /jcc.2018.v2i2.3061

Solihatun, S., \& Folastri, S. (2019). Program bimbingan dan konseling untuk mengatasi kesulitan belajar siswa SD Negeri 05 Ciganjur Jakarta Selatan. TERAPUTIK: Jurnal Bimbingan Dan Konseling, 3(1), 35-40. https://doi.org/10.30998/teraputik.3112 Suhendra, A. (2018). Analisis faktor eksternal pembelajaran. Darul Ilmi: Jurnal Ilmu Kependidikan Dan Keislaman, 6(2), 1-13.

Sujarweni, V. W. (2014). Metode penelitian: Lengkap, praktis, dan mudah dipahami. Yogyakarta: Pustaka baru press.

Suprayitno, A., \& Wahyudi, W. (2020). Pendidikan karakter di era milenial. Deepublish.

Taufik, I. N. (2014). Kajian kesulitan belajar pada siswa kelas III Sekolah Dasar Negeri 2 Cihalimun Kec. Kertasari Kab. Bandung. Deiksis Jurnal Pendidikan Bahasa Dan Sastra Indonesia, 1(1).

Tohirin, B. (2009). Konseling di sekolah dan Madrasah. Jakarta: Rajawali Pers.

Tutuk, N. (2015). Implementasi pendidikan karakter.

Wahyuni, M., Ilyas, A., \& Yusri, Y. (2013). Pelaksanaan kunjungan rumah oleh Guru Bk/Konselor di SMA Negeri Kota Padang. Konselor, 2(2).

Wardani, A., \& Ayriza, Y. (2020). Analisis kendala orang tua dalam mendampingi anak belajar di rumah pada masa 
Kontribusi Kunjungan Rumah - Solihatun, Hayu Stevani \& Sisca Folastri

pandemi Covid-19. Jurnal Obsesi: Jurnal

Pendidikan Anak Usia Dini, 5(1), 772-782.

Westwood, P. S. (2004). Learning and learning difficulties: A handbook for teachers.

Aust Council for Ed Research. 